Al-Muaddib : Jurnal Ilmu-Ilmu Sosial \& Keislaman http://jurnal.um-tapsel.ac.id/index.php/al-muaddib/ issn online : 2549-0427 | issn cetak : 2528-2492 Volume 1 Nomor 2 ( Januari-Juni) 2019

\title{
KETERAMPILAN GURU PENDIDIKAN AGAMA ISLAM (PAI) DALAM PENGELOLAAN KELAS DI SMP NEGERI 2 RAO UTARA KABUPATEN PASAMAN
}

\author{
HILMI \\ Dosen Universitas Muhammadiyah Tapanuli Selatan \\ Email:Annahilmi92@gmail.com
}

\begin{abstract}
A teacher is expected to be capable and professional in the field of education, one of which is in terms of classroom management during the learning process. To manage this, good teacher management is needed, because classroom management is an effort to create and maintain optimal conditions in order for an effective learning process to occur. Based on the results of research in SMP 2 Rao Utara, Islamic Religious Education Teachers (PAI) are still less skilled in managing a good class of skills related to the creation and maintenance of optimal (preventive) learning conditions and skills related to the optimal return of learning conditions ( curative). This can be seen from the lack of classroom management components implemented such as the lack of teacher responsiveness in terms of looking at students carefully, during the learning process the teacher always looks at the student as a whole, but when students do the assignment the teacher gives less attention to students so the class is not conducive.
\end{abstract}

Keywords: PAI Teacher Skills, Class Management

\section{Pendahuluan}

Pendidikan merupakan kebutuhan dasar bagi setiap individu yang hidup di jagat raya ini, karena pendidikan adalah usaha yang dilakukan dalam proses pencapaian kedewasaan. Di samping itu untuk mencapai pendidikan yang optimal maka dibutuhkan interaksi antara guru, siswa, lingkungan, dan masyarakat.

Menurut undang-undang Republik Indonesia No. 20 tahun 2003 tentang sistem pendidikan Nasional pasal 1, menyatakan bahwa pendidikan adalah:

Usaha sadar dan terencana untuk mewujudkan suasana belajar dan proses pembelajaran agar peserta didik secara aktif mengembangkan potensi dirinya untuk memiliki kekuatan spiritual, keagamaan, pengendalian diri, kepribadian, kecerdasan, akhlak mulia, serta keterampilan yang diperlukan dirinya, masyarakat, bangsa dan Negara. ${ }^{1}$

Semua orang yang hidup di dunia ini memerlukan pendidikan, dengan pendidikan orang memiliki ilmu. Ilmu dapat menuntun seseorang untuk menjalani kehidupan dunia dan akhirat dan ilmu juga dapat menuntun seseorang ke arah yang lebih baik, dengan ilmu seseorang akan ditinggikan derajatnya oleh Allah SWT. Sebagaimana dalam firman Allah Q.S Al-Mujadalah ayat 11:

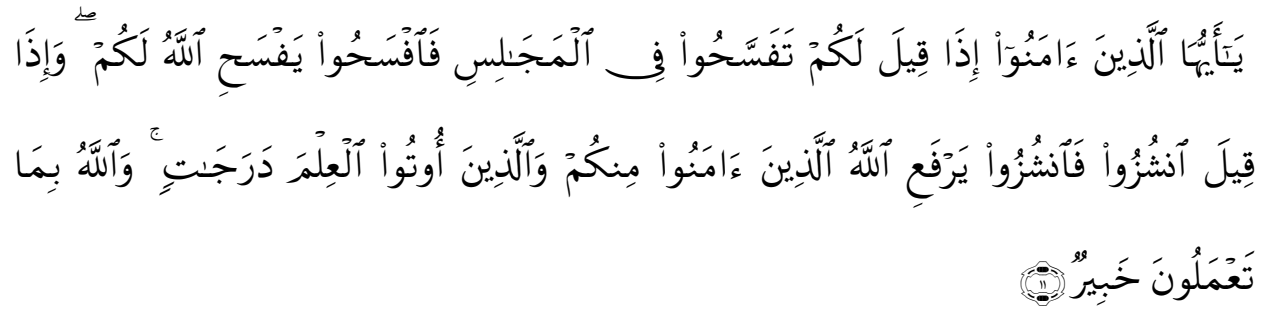

Artinya:

\footnotetext{
${ }^{1}$ Undang-Undang SISDIKNAS, (Jakarta: Sinar Grafika,2003), h.2
} 
Al-Muaddib : Jurnal Ilmu-Ilmu Sosial \& Keislaman http://jurnal.um-tapsel.ac.id/index.php/al-muaddib/ issn online : 2549-0427 | issn cetak : 2528-2492 Volume 1 Nomor 2 ( Januari-Juni) 2019

"Hai orang-orang beriman apabila dikatakan kepadamu: "Berlapang-lapanglah dalam majlis", Maka lapangkanlah niscaya Allah akan memberi kelapangan untukmu. dan apabila dikatakan: "Berdirilah kamu", Maka berdirilah, niscaya Allah akan meninggikan orang-orang yang beriman di antaramu dan orang-orang yang diberi ilmu pengetahuan beberapa derajat. dan Allah Maha mengetahui apa yang kamu kerjakan.”

Dalam ayat di atas dijelaskan bahwa orang yang memiliki pengetahuan akan ditinggikan kedudukannya oleh Allah beberapa derajat dibandingkan dengan orang yang tidak memiliki pengetahuan sama sekali. Ini membuktikan bahwa orang yang menuntut ilmu lebih mulia di sisi Allah dibandingkan dengan orang yang tidak menuntut ilmu.

Pendidikan Agama merupakan satu hal yang sangat penting bagi diri individu karena dengan pendidikan Agama seseorang dapat menyeimbangkan kehidupan dunia dan akhiratnya. Demikian pentingnya pendidikan, maka Islam mewajibkan bagi setiap muslim untuk menuntut ilmu pengetahuan. Menuntut ilmu bagi manusia adalah merupakan hal yang terpenting dalam kehidupan manusia, ilmu pengetahuan dapat diperoleh dari belajar.

Salah satu pendidikan agama yaitu Pendidikan Agama Islam, Pendidikan Agama Islam adalah upaya sadar dan terencana dalam menyiapkan peserta didik untuk mengenal, menghayati hingga mengimani ajaran agama Islam, dibarengi dengan tuntutan untuk menghormati penganut ajaran agama lain dalam hubungannya dengan kerukunan antar

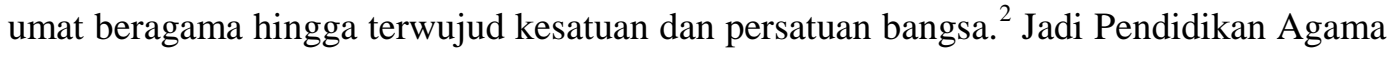
Islam adalah usaha sadar yang dilakukan pendidik dalam rangka mempersiapkan peserta didik untuk meyakini, memahami, dan mengamalkan ajaran agama Islam melalui pengamalan, pengajaran dan bimbingan untuk mencapai tujuan yang telah ditetapkan yaitu kebahagiaan dunia dan akhirat.

Menurut Zakiah Drajat Pendidikan Agama Islam adalah usaha bimbingan dan asuhan terhadap anak didik agar nantinya setelah selesai dari pendidikan dapat memahami apa yang terkandung di dalam Islam secara keseluruhan, menghayati makna dan maksud serta tujuannya dan pada akhirnya dapat mengamalkannya serta menjadikan ajaran agama Islam yang telah dianutnya tersebut sebagai pandangan hidupnya sehingga dapat mendatangkan keselamatan dunia dan akhirat kelaknya. ${ }^{3}$

Mata pelajaran Pendidikan Agama Islam tersebut adalah mata pelajaran yang mencakup (ruang lingkup) di dalamnya Fikih, Akidah Akhlak, Al-Qur'an Hadits, dan Sejarah Kebudayaan Islam (SKI). Defenisi lain mengatakan bahwa ruang lingkup Pendidikan Agama Islam adalah perwujudan keserasian, keselarasan, dan keseimbangan hubungan manusia dengan Allah SWT, diri sendiri, sesama manusia, makhluk lainnya, maupun lingkungan anak-anak. ${ }^{4}$

Pada hakekatnya kegiatan belajar mengajar adalah suatu proses interaksi atau hubungan timbal balik antara guru dan siswa dalam suatu pembelajaran. ${ }^{5}$ Guru sebagai salah satu komponen dalam proses belajar mengajar merupakan pemegang peran yang

\footnotetext{
${ }^{2}$ Abdul Majid, Pendidikan Agama Islam Berbasis Kompetensi, (Bandung: Remaja Rosdakarya, 2006), h.72

${ }^{3}$ Zakiah Drajat, Ilmu Pendidikan Islam, (Jakarta: PT.Bumi Aksara, 1990), h.88

${ }^{4}$ Abdul Majid, Pendidikan Agama Islam Berbasis Kompetensi, ...,h.73

${ }^{5}$ Nana Sudjana, Dasar-dasar Proses Belajar Mengajar, (Bandung: Sinar Baru Algesindo, 2011), h.28
} 
sangat penting. Guru bukan hanya sekedar penyampai materi saja, tetapi lebih dari itu guru dapat dikatakan sebagai sentral pembelajaran.

Guru sebagai fasilitator dalam proses belajar mengajar yang bertugas menciptakan situasi dan kondisi yang memungkinkan terjadinya proses belajar mengajar yang lebih efektif dan efisien. ${ }^{6}$ Sebelum mengajar, guru harus merencanakan kegiatan pengajaran secara sistematis, sehingga dapat terampil dalam proses belajar mengajar. Profesional adalah pekerjaan atau kegiatan yang dilakukan oleh seseorang dan menjadi sumber penghasilan kehidupan yang memerlukan keahlian, kemahiran atau kecakapan yang memenui standar mutu atau norma tertentu serta memerlukan pendidikan profesi. ${ }^{7}$

Pada intinya guru yang profesional adalah guru yang memiliki kompetensi yang disyaratkan untuk melakukan tugas pendidikan dan pengajaran. Oleh karena itu, membedah aspek profesionalisme guru berarti mengkaji kompetensi yang harus dimiliki oleh seorang guru. ${ }^{8}$

Pendukung terwujudnya pendidikan tersebut seluruh kompetensi yang berhubungan dengan pendidikan mesti melakukan kerja sama yang sinergis, sehingga tujuan pendidikan tersebut terealisasi suatu keniscayaan bahwa guru Pendidikan Agama Islam mesti mengembangkan potensi pribadi, professional dan sosialnya sehingga pelaksanaan pengajaran peserta didik dapat terlaksana secara optimal dan maksimal. Pendidikan Agama Islam merupakan kegiatan pokok guru agama yang mengupayakan terwujudnya manusia yang seutuhnya dan cakap keterampilannya.

Keterampilan mengajar bagi seorang guru adalah sangat penting kalau ingin menjadi seorang guru professional, Keterampilan mengajar adalah kecakapan atau kemampuan guru dalam menyajikan materi pelajaran. ${ }^{9}$ Jadi disamping harus menguasai substansi bidang studi yang dipegang. Keterampilan dasar mengajar juga adalah merupakan keterampilan menunjang untuk keberhasilan dalam proses pembelajaran. Guru sebagai salah seorang yang berperan aktif dalam pendidikan, harus professional dalam menempati kedudukannya. Untuk itu guru di tuntut punya keterampilan dasar mengajar, yaitu keterampilan yang mutlak dimiliki oleh guru. Berkenaan dengan itu ada beberapa keterampilan dasar mengajar, yaitu:

a. Keterampilan Bertanya

b. Keterampilan Memberi penguatan

c. Keterampilan Mengadakan variasi

d. Keterampilan Menjelaskan

e. Keterampilan Membuka dan menutup pelajaran

f. Keterampilan Membimbing diskusi kelompok kecil

g. Keterampilan Mengelola kelas

h. Keterampilan Mengajar perseorangan. ${ }^{10}$

Guru terampil sebaiknya melakukan berbagai upaya untuk peningkatan prestasi belajar siswa, hal tersebut merupakan tanggung jawab semua guru dalam memperoleh kualitas sumber daya manusia untuk mewujudkan hal di atas seorang guru di tuntut untuk

\footnotetext{
${ }^{6}$ Wina Sanjaya, Strategi Pembelajaran, (Jakarta: PT. Rineka Cipta, 1966), h.33

${ }^{7}$ UU No. 14 tahun 2005 tentang Guru dan Dosen, (Bandung: Fermana, 2006). 4

${ }^{8}$ Syafrudin Nurdin, Basyiruddin Usman, Guru Profesional dan Implementasi Kurikulum, (Jakarta: Ciputat press, 2004).

${ }^{9}$ Zainal Asri, Micro Teaching, (Jakarta: PT. Raja Grafindo, 2012), h. 6

${ }^{10}$ Syaiful Bahri Djamarah, Guru Dan Anak Didik Dalam Interaksi Edukatif, (Jakarta: PT. Rineka Cipta, 2000), h. 99
} 
memiliki keterampilan mengajar. Salah satu keterampilan yang harus dimiliki seorang guru dalam melaksanakan proses belajat mengajar adalah keterampian pengelolaan kelas. Keterampilan pengelolaan keles merupakan suatu keterampilan yang sangat perlu sekali digunakan oleh guru dalam proses belajar mengajar, karena keterampilan pengelolaan kelas ini merupakan suatu keterampilan yang digunakan oleh guru dalam mengatur kondisi kelas supaya terjadi proses pembelajaran secara efektif dan efisien.

Pengelolaan kelas adalah keterampilan guru meciptakan dan memelihara kondisi belajar yang optimal dan mengembalikannya bila terjadi gangguan dalam proses interaksi edukatif. ${ }^{11}$ Contohnya penghentian tingkah laku anak didik yang menyelewengkan perhatian kelas, pemberian ganjaran bagi ketepatan waktu penyelesaian tugas anak didik, atau penetapan norma kelompok yang produktif.

Tentu pengelolaan kelas yang seperti ini harus dilakukan oleh semua guru, salah satunya adalah guru bidang studi Pendidikan Agama Islam. Mata pelajaran Pendidikan Agama Islam ini dipelajari salah satunya disebuah sekolah tepatnya di SMP Negeri 2 Rao Utara.

Berdasarkan survei awal di SMP Negeri 2 Rao Utara dimana diperoleh kenyataan bahwa masih terlihat guru yang kurang optimal dalam menggunakan keterampilan yang berhubungan dengan penciptaan dan pemeliharaan kondisi belajar yang optimal dan keterampilan yang berhubungan dengan pengembalian kondisi belajar yang optimal. Ketika terjadi keributan dalam proses pembelajaran guru sulit untuk mengembalikan konsentrasi siswa, siswa bicara sama teman sebangkunya, siswa sibuk dengan aktivitas yang tidak berhubungan dengan pembelajaran PAI. Seharusnya guru mampu mengantisipasi hal ini dengan menggunakan keterampilan mengajar. Berangkat dari permasalahan ini peneliti terdorong untuk meneliti dan membahas masalah ini dalam sebuah karya ilmiah yang berjudul: "Keterampilan Guru Pendidikan Agama Islam (PAI) Dalam Pengelolaan Kelas Di SMP Negeri 2 Rao Utara”.

Penelitian ini bertujuan untuk mengetahui pelaksanaan keterampilan guru PAI dalam pengelolaan kelas yang berhubungan dengan penciptaan dan pemeliharaan kondisi belajar yang optimal dan keterampilan yang berhubungan dengan pengembalian kondisi belajar yang optimal.di kelas VIII SMP Negeri 2 Rao Utara.

Secara teoritis kegunaan penelitian ini adalah:

a. Memberikan sumbangan pemikiran terhadap guru bidang studi dalam meningkatkan keterampilan guru PAI dalam pengelolaan kelas di SMP Negeri 2 Rao Utara

b. Untuk memenuhi salah satu syarat untuk memperoleh gelar sarjana

Secara praktis Kegunaan penelitian ini adalah:

a. Untuk menambah wawasan penulis menyangkut ilmu yang penulis miliki

b. Sebagai bahan bacaan bagi sekolah yang bersangkutan

\section{METODE PENELITIAN}

Jenis penelitian merupakan penelitian lapangan (field research), yaitu penelitian yang dilakukan dalam kehidupan yang sebenarnya. Pada hakikatnya merupakan metode untuk menemukan secara spesifik dan realis tentang apa yang terjadi pada sesuatu saat di tengah-tengah masyarakat. Dengan memakai pendekatan kualitatif dengan metode deskriptif, serta menganalisis suatu peristiwa atau kejadian yang terjadi di lapangan sebagaimana adanya. Sumber data yang digunakan primer dan sekunder. Teknik

\footnotetext{
${ }^{11}$ Syaiful Bahri Djamarah, Guru..., h. 144
} 
pengumpulan data melalui observasi, wawancara dan dokumentasi, data yang dikumpulkan kemudian diolah dengan cara reduksi data, menyajikan data kemudian verifikasi data lalu ditarik kesimpulan dan dianalisis secara kualitatif, kemudian dilakukan uji keabsahan data dengan uji kredibilitas, transferability, realibilitas, kemudian kompirmability.

\section{HASIL PENELITIAN DAN PEMBAHASAN}

A. Keterampilan yang berhubungan dengan penciptaan dan pemeliharaan kondisi belajar yang optimal (bersifat preventif).

1. Sikap tanggap

Sikap tanggap ini dapat diperlihatkan dengan perhatian dan keterlibatan guru terhadap setiap perilaku siswa di kelas. Dengan sikap tanggap ini siswa akan merasa guru hadir bersama mereka dan tau apa yang mereka kerjakan. Kesan ketanggapan ini dapat ditunjukkan dengan berbagai cara seperti berikut:

a. Memandang secara seksama

Memandang secara seksama dapat mengundang dan melibatkan anak didik dalam kontak pandang serta interaksi antar pribadi. Hal ini dapat dilakukan dengan pendekatan guru untuk bercakap-cakap, bekerja sama, dan menunjukkan rasa persahabatan.

Berdasarkan observasi yang penulis lakukan di SMP Negeri 2 Rao Utara, pada saat pembelajaran berlangsung guru selalu memandang siswa secara keseluruhan, tetapi ketika siswa mengerjakan tugas guru kurang memberikan perhatian atau pandangannya kepada siswa.

Hal ini diperkuat dengan wawancara yang penulis lakukan terhadap siswa kelas VIII SMP Negeri 2 Rao Utara sebagai berikut:

"Di dalam proses pembelajaran guru telah memperhatikan kami semua, tetapi apabila ada tugas yang diberikan kepada kami, guru jarang sekali memberikan perhatiannya sehingga suasana kelas tidak kondusif" 12

Berdasarkan observasi dan wawancara yang penulis lakukan, dapat disimpulkan bahwa dalam pembelajaran guru telah membagi kontak pandang terhadap seluruh siswa.Namun ketika guru memberikan tugas, guru justru sibuk dengan kegiatan lain tanpa memperhatikan siswa. Seharusnya dalam pemberian tugas ini guru tetap memperhatikan seluruh siswa. Guru terlibat di dalamnya, setidaknya guru membantu siswa yang tidak paham dengan tugas yang diberikan.

b. Gerak mendekati

Gerak guru dalam posisi mendekati kelompok kecil atau individu menandakan kesiagaan, minat dan perhatian guru yang diberikan terhadap tugas serta aktifitas anak didik.Gerak mendekati hendaknya dilakukan secara wajar, bukan untuk menakut-nakuti, mengancam atau memberi kritikan atau hubungan.

Berdasarkan observasi yang penulis lakukan di SMP Negeri 2 Rao Utara penulis melihat bahwa guru tidak pernah memberikan perhatian kepada siswa dengan mendekati mereka.

\footnotetext{
${ }^{12}$ Maimunah, Siswi Kelas VIII, Wawancara Pribadi, Koto Nopan, Tgl: 26 Mei 2014
} 
Hal ini diperkuat dengan wawancara yang penulis lakukan terhadap siswa kelas VIII SMP Negeri 2 Rao Utara sebagai berikut:

"Saya merasa tidak pernah didekati oleh guru ketika proses pembelajaran berlangsung walaupun ada bentuk-bentuk saya akan mengganggu siswa lain dalam belajar"

Berdasarkan observasi dan wawancara yang penulis lakukan, dapat disimpulkan bahwadalam menunjukkan sikap tanggap guru tidak pernah memperhatikan peserta didik dengan cara mendekati mereka. Hal tersebut dapat diketahui ketika guru memberikan tugas, ada aktifitas siswa yang kurang baik seperti mencontek, guru selalu menegur mereka tanpa mendekati siswa tersebut.Seharusnya ketika ada gejala-gejala yang tidak baik mulai terlihat oleh guru, guru dapat menegur siswa tersebut dengan mendekati mereka.Gerak mendekati ini juga dapat digunakan guru untuk meninjau aktifitas siswa. Guru dapat menghampiri siswa dan menanyakan kesulitankesulitan yang mereka dialami.

c. Memberi pernyataan

Pernyataan guru terhadap sesuatu yang dikemukakan oleh anak didik sangat diperlukan. Ini dapat berupa tanggapan, komentar, ataupun yang lainnya. Namun guru perlu menghindari hal-hal yang menunjukkan bahwa kelas didominasi oleh guru.

Berdasarkan observasi yang penulis lakukan di SMP Negeri 2 Rao Utara penulis melihat bahwa setiap siswa mengemukakan sesuatu baik berupa pendapat atau hal lainya guru selalu memberikan komentar terhadap pendapat siswa tersebut.

Hal ini diperkuat dengan wawancara yang penulis lakukan terhadap siswa kelas VIII SMP Negeri 2 Rao Utara sebagai berikut:

"Bapak selalu memberikan komentar yang terhadap aktifitas yang telah dilakukan siswa.Selama mengajar bapak juga tidak pernah memberikan komentar yang menyudutkan kami". ${ }^{13}$

Berdasarkan observasi dan wawancara yang penulis lakukan, dapat disimpulkan bahwa dalam menunjukkan sikap tanggap guru selalu memberikan respon yang positif yaitu dengan mengomentari setiap aktifitas yang dilakukan siswa. Ini merupakan hal baik yang dilakukan oleh guru dengan komentar yang diberikan siswa akan merasa senang melakukan aktifitas yang baik dan enggan untuk melakukan aktifitas yang kurang baik. Berdasarkan hasil penelitian guru juga tidak pernah memberikan pernyataan yang mengandung ancaman sehingga siswa merasa senang belajar dengan guru.

2. Memberi perhatian.

Pengelolaan kelas yang efektif terjadi bila guru mampu memberi perhatian kepada beberapa kegiatan yang berlangsung dalam waktu yang sama. Membagi perhatian dapat dilakukan dengan dua cara yaitu visual dan verbal.

Berdasarkan observasi yang penulis lakukan di SMP Negeri 2 Rao Utara, Guru Pendidikan Agama Islam telahmemberikan perhatian kepada siswa dengan

\footnotetext{
${ }^{13}$ Borkat, Siswa Kelas VIII, Wawancara Pribadi, Koto Nopan, Tgl: 26 Mei 2014
} 
perhatian dengan membagi kontak pandang kepada seluruh siswa di kelas serta menberikan komentar terhadap setiap aktifitas yang dilakukan siswa.

Hal ini diperkuat dengan wawancara yang penulis lakukan terhadap guru Pendidikan Agama Islam di SMP Negeri 2 Rao Utara sebagai berikut:

"Dalam memberikan perhatian kepada siswa dapat saya lakukan dengan menjaga kontak pandang kepada seluruh siswa.Saya tidak menfokuskan perhatian hanya kepada beberapa orang siswa saja.Saya juga memberikan perhatian kepada siswa dengan memberikan komentar terhadap setiap aktifitas siswa". ${ }^{14}$

Berdasarkan observasi dan wawancara yang penulis lakukan, dapat disimpulkan bahwa guru Pendidikan Agama Islam dalam memberikan perhatian kepada siswanya ada yang berbentuk visual dan ada yang berbentuk verbal. Guru telah membagi kontak mata kepada seluruh siswa dan memberikan komentar terhadap aktifitas siswa. menurut penulis hal ini sudah sangat baik diterapkan oleh guru. Dengan pemberian perhatian ini siswa akan merasa tersanjung dan termotivasi untuk melakukan aktifitas yang baik.

3. Memusatkan Perhatian Kelompok

Kegiatan siswa dalam pembelajaran dapat dipertahankan apabila dari waktu ke waktu guru mampu memusatkan perhatian kelompok terhadap tugas yang dilakukan. Hal ini dapat dilakukan dengan cara sebagai berikut:

a. Menyiagakan peserta didik

Menyiagakan peserta didik ini artinya memusatkan perhatian peserta didik kepada suatu hal sebelum guru menyampaikan materi pokok.Hal ini bertujuan untuk menghidari penyimpangan perhatian peserta didik.

Berdasarkan observasi yang penulis lakukan di SMP Negeri 2 Rao Utara sebelum menyampaikan materi pembelajaran guru tidak pernah memusatkan perhatian siswa.Setelah masuk kelas guru langsung masuk ke topic pembelajaran dan langsung menjelaskan materi pelajaran.

Hal ini diperkuat dengan wawancara yang penulis lakukan terhadap siswa kelas VIII SMP Negeri 2 Rao Utara sebagai berikut:

"Sebelum memulai pembelajaran Bapak meminta kami berdoa dan beliau langsung menuliskan pokok materi di depan kelas dan menjelaskan materi per sub materi”.

Berdasarkan observasi dan wawancara yang penulis lakukan, dapat disimpulkan bahwa guru tidak memusatkan perhatian siswa terhadap materi yang akan dijelaskan. Setelah berdoa guru langsung memulai menjelaskan materi. Seharusnya hal utama yang harus diperhatikan oleh guru sebelum menjelaskan materi adalah mengajak siswa untuk benar-benar memfokuskan pikiran mereka terhadap materi yang akan dibahas. Hal ini bertujuan agar siswa tidak memikirkan hal-hal yang menyimpang dari materi pembelajaran.

${ }^{14}$ A.Rahman, S.Ag, Guru Pendidikan Agama Islam, Wawancara Pribadi, Koto Nopan, Tgl: 30 Mei 2014 
b. Menuntut Tanggung Jawab Peserta Didik

Hal ini berhubungan dengan cara guru memegang teguh kewajiban dan tanggung jawab yang dilakukan oleh siswa serta keterlibatan siswa dalam tugas-tugas.

Berdasarkan observasi yang penulis lakukan di SMP Negeri 2 Rao Utara, penulis melihat bahwa ketika guru memberikan tugas kepada siswa. Setelah siswa selesai mengerjakan tugas, guru meminta mereka mengumpulkan tugas tersebut tanpa bertanya siapa yang tidak mengerjakan.Sehingga ada beberapa orang siswa yang tidak mengerjakan tugas yang dberikan.

Hal ini diperkuat dengan wawancara yang penulis lakukan terhadap siswa kelas VIII SMP Negeri 2 Rao Utara sebagai berikut:

"Ketika memberikan tugas Bapak selalu meminta kami mengumpulkan tugas tersebut ke meja guru.Bapak tidak pernah bertanya siapa yang tidak mengerjakan.Sehingga ada beberapa orang teman yang dengan santai tidak mengerjakan tugas yang diberikan”.

Berdasarkan observasi dan wawancara yang penulis lakukan, dapat disimpulkan bahwa dalam memusatkan perhatian kelompok guru tidak pernah menuntut tanggung jawab siswa seperti mengecek siswa yang tidak mengerjakan tugas yang diberikan sehingga ada beberapa orang siswa yang sengaja tidak mengerjakan tugas.Seharusnya guru perlu meminta pertanggungjawaban seluruh siswa terhadap tugas yang diberikan. Guru dapat meminta siswa melaporkan tugas itu dan memberikan respon terhadap tugas yang diberikan. Selain itu yang perlu diperhatikan guru adalah memberikan penilaian disetiap tugas yang diberikan.

c. Penghentian

Apabila terjadi tingkah laku peserta didik yang mengganggu kelas hendaknya guru menegurnya secara verbal. Guru dapat menghampiri siswa dan memberikan nasehat yang menghentikan perilaku siswa tersebut.

Berdasarkan observasi yang penulis lakukan di SMP Negeri 2 Rao Utara, penulis melihat bahwa guru telah menegur siswa yang mengganggu kelas.Namun penulis melihat teguran itu tidak begitu dihiraukan oleh siswa.

Hal ini diperkuat dengan wawancara yang penulis lakukan terhadap siswa kelas VIII SMP Negeri 2 Rao Utara sebagai berikut:

"ketika ada diantara kami yang mengganggu proses pembelajaran Bapak selalu menegur kami. Namun ada beberapa orang siswa yang walaupun sudah ditegur malah tetap melakukan perbuatan yang sama”.

Berdasarkan observasi dan wawancara yang penulis lakukan, dapat disimpulkan bahwa guru telah melakukan penghentian dengan cara menegur siswa yang mengganggu proses pembelajaran. Namun masih ada siswa yang tetap mengganggu kelas walaupun susdah ditegur.Menurut analisis penulis hal ini dapat disebabkan karena teguran yang diberikan guru kurang efektif, artinya dalam memberikan teguran guru kurang tegas. Seharusnya dalam memberikan teguran hendaknya guru itu tegas dan teguran itu jelas tertuju kepada peserta didik yang mengganggu serta kepada tingkah lakunya yang menyimpang.Dalam memberikan teguran guru dilarabg keras memberi 
peringatan yng kasar yang mengandung penghinaan serta ocehan yang berkepanjangan.

4. Penguatan

Penguatan yang dimaksudkan dapat berupa rewarddan punishmentyang bersifat non material juga yang bersifat material tapi tidak berlebihan. Penguatan ini dapat dilakukan dengan pemberian pujian dan sanksi terhadap siswa yang mengganggu ketertiban kelas.

Berdasarkan observasi yang penulis lakukan di SMP Negeri 2 Rao Utara guru selalu menangkap siswa yang mengganggu kenyaman belajar dan menasehatinya. Namun guru tidak pernah memberikan reward terhadap siswa yang melakukan perbuatan positif.

Hal ini diperkuat dengan wawancara yang penulis lakukan terhadap siswa kelas VIII SMP Negeri 2 Rao Utara sebagai berikut:

"Bapak selalu memberikan hukuman kepada siswa yang meribut di dalam kelas dan mnasehatinya namun bapak tidak pernah memberikan hadiah kepada siswa yang berlaku baik". ${ }^{15}$

Berdasarkan observasi dan wawancara yang penulis lakukan, dapat disimpulkan bahwa dalam memberikan penguata, guru hanya memberikan penguatan terhadap siswa yang mengganggu yaitu memberikan punishment yang berupa teguran dan hukuman.Seharusnya dalam memberikan penguatan ini diseimbang baik terhadap perilaku yang positif ataupun yang negatif. Guru hendaknya memberikan reward terhadap siswa yang berperilaku positif sehingga siswa termotivasi untuk mengulangi perbuatan yang sama bahkan lebih. Reward ini sekurang-kurangnya dapat diberikan dengan pujian. Begitu pula dalam memberikan punishment, hendaknya hukuman yang diberikan mengandung unsure jera bagi siswa. Dengan punishment yang diberikan siswa takut untuk mengulangi perbuatan yang sama.

B. Keterampilan yang berhubungan dengan pengembalian kondisi belajar yang optimal (bersifat kuratif).

Keterampilan ini berkaitan dengan respon guru terhadap anak didik yang berkelanjutan dengan maksud agar guru dapat mengadakan kegiatan remedial untuk mengembalikan kondisi belajar yang optimal. Apabila terdapat anak didik yang menimbulkan gangguan yang berulang-ulang walaupun guru telah menggunakan tingkah laku dan tanggapan yang sesuai, guru dapat meminta bantuan kepala sekolah, konselor sekolah, atau orang tua anak didik untuk membantu mengatasinya.

Bukanlah kesalahan profesional guru apabila ia tidak dapat menangani setiap masalah anak didik dalam kelas. Namun pada tingkat tertentu guru dapat menggunakan seperangkat strategi untuk tindakan perbaikan terhadap tingkah laku anak didik yang terus menerus menimbulkan gangguan dan yang tidak mau terlibat dalam tugas kelas. Strategi itu adalah:

1. Memodifikasi tingkah laku

Guru hendaknya menganalisis tingkah laku peserta didik yang mengalami masalah atau kesulitan dan berusaha memodifikasi tingkah laku tersebut dengan mengaplikasikan pemberian penguatan secara sistematis.

\footnotetext{
${ }^{15}$ Usman, Siswa Kelas VIII, Wawancara Pribadi, Koto Nopan, Tgl: 26 Mei 2014
} 
Al-Muaddib : Jurnal Ilmu-Ilmu Sosial \& Keislaman http://jurnal.um-tapsel.ac.id/index.php/al-muaddib/ issn online : 2549-0427 | issn cetak : 2528-2492 Volume 1 Nomor 2 ( Januari-Juni) 2019

Berdasarkan observasi yang penulis lakukan di SMP Negeri 2 Rao Utara bahwa ketika ada siswa yang bermasalah cara guru PAI memodifikasi tingkah laku siswa itu dengan cara menasehati siswa.

Hal ini diperkuat dengan wawancara yang penulis lakukan terhadap guru Pendidikan Agama Islam sebagai berikut:

"Dalam mengubah tingkah laku siswa dapat saya lakukan denganmenasehati atau menegur supaya siswa tersebut hendaknya benar-benar sekolah, karena saya mendidik dia menjadi orang baik. Sedangkan kalau menukar atau memindahkan siswa jarang dilakukan, biasanya dengan teguran saja". ${ }^{16}$

Pernyataan ini diperkuat dengan wawancara yang penulis lakukan terhadap siswa kelas VIII SMP Negeri2 Rao Utara sebagai berikut:

"Ditegur dan dinasehati bahwa orang tua kita sudah susah payah mencari rezeki untuk kita". ${ }^{17}$

Berdasarkan observasi dan wawancara yang penulis lakukan dapat disimpulkan bahwa guru memodifikasi tingkah laku siswa dengan cara menasehati siswa. Namun penulis melihat hal ini tidak ada perubahan pada diri siswa.setelah dinasehati hanya beberapa waktu saja siswa berubah kemudian mengulangi masalah yang sama. Menurut penulis menasehati saja tidaklah cukup dalam memodifikasi tingkah laku siswa.Dalam memodifikasi tingkah laku siswa hendaknya dapat dilakukan dengan pemberian penguatan yang sistematis dan berkelanjutan. Guru dapat memberikan hukuman sampai siswa jera dan tidak mengulang perilaku yang sama. Jika tidak ada juga perubahan guru dapat menghadapkan siswa kepada guru Bimbingan Konseling atau pemanggilan orang tua.

2. Menggunakan Pendekatan Pemecahan Masalah

Dalam mengembalikan kondisi belajar guru dapat menggunakan pendekatan pemecahan masalah kelompok dengan cara memperlancar tugas, memelihara kegiatan-kegiatan kelompok dan menemukan serta memecahkan tingkah laku yang menimbulkan masalah.

Berdasarkan observasi yang penulis lakukan di SMP Negeri2 Rao Utara dalam mengembalikan kondisi belajar guru telah menggunakan pendekatan pemecahan masalah dengan menemukan dan memecahkan tingkah laku yang menimbulkan masalah. Guru mengumpulkan siswa dengan masalah yang sama, kemudian menanyakan apa yang sebenarnya menjadi permasalahan dan mencari solusinya bersama-sama.

Pernyataan ini diperkuat dengan wawancara yang penulis lakukan terhadap siswa kelas VIII SMP Negeri 2 Rao Utara sebagai berikut: ${ }^{18}$

"Apabila ada diantara kami melakukan gangguan yang berulang-ulang, guru telah melakukan cara-cara agar siswa melakukan perubahan namun tidak ada perubahan maka guru mengumpulkan siswa yang bermasalah

${ }^{16}$ A.Rahman, S.Ag, Guru Pendidikan Agama Islam, Wawancara Pribadi, Koto Nopan, Tgl: 30 Mei 2014

${ }^{17}$ Usman, Siswa Kelas VIII, Wawancara Pribadi, Koto Nopan, Tgl: 26 Mei 2014

${ }^{18}$ Gusnarti Sumariani, Siswi Kelas VIII, Wawancara Pribadi, Koto Nopan, Tgl: 26 Mei 
dan mencari solusi dari permasalahan yang dihadapi secara bersamasama”.

Berdasarkan observasi dan wawancara yang dilakukan dapat disimpulkan bahwa dalam mengembalikan kondisi belajar guru telah menggunakan pendekatan pemecahan masalah dengan cara menemukan dan memecahkan tingkah laku yang menimbulkan masalah. Guru menganalisis apa yang sebenarnya menjadi permasalahan bagi siswa tersebut dan mencari solusi dari permasalahan tersebut. Menurut analisis penulis dalam mengembalikan kondisi kelas dapat dilakukan guru dengan pemberian tugas. Guru berusaha agar terjadi kerja sama yang baik dalam pelaksanaan tugas. Selain itu guru perlu menyemangati siswa dan menangani komplik yang timbul.

\section{KESIMPULAN}

Berdasarkan penelitian yang penulis lakukan di SMP Negeri 2 Rao dapat disimpulkan bahwa keterampilan pengelolaan kelas guru Pendidikan Agama Islam masih dikatakan belum terampil maksimal baik dari Keterampilan yang berhubungan dengan penciptaan dan pemeliharaan kondisi belajar yang optimal (bersifat preventif) maupun Keterampilan yang berhubungan dengan pengembalian kondisi belajar yang optimal (bersifat kuratif). Hal ini dapat dilihat dari kurangnya komponen-komponen pengelolaan kelas terlaksanakan seperti:

1. Kurangnya sikap tanggap guru dalam hal memandang siswa secara seksama pada saat pembelajaran berlangsung guru selalu memandang siswa secara keseluruhan, tetapi ketika siswa mengerjakan tugas guru kurang memberikan perhatian, guru jarang memberikan perhatian kepada siswa dengan mendekati mereka atau pandangannya kepada siswa. Pemusatan perhatian individu maupun kelompok contohnya sebelum menyampaikan materi pembelajaran guru jarang memusatkan perhatian siswa, setelah masuk kelas guru langsung masuk ke topik pembelajaran dan langsung menjelaskan materi pelajaran.

2. Dalam memodifikasi tingkah laku siswa guru belum melakukannya secara optimal cara guru memodifikasi tingkah laku siswa hanya dengan menasehati saja, setelah dinasehati siswa bisa berubah tetapi dalam waktu yang dekat siswa mengulangi kesalahan yang sama lagi.

Berdasarkan kesimpulan diatas, maka penulis memberikan beberapa saran yang diajukan kepada :

1. Kepada guru yang mengajar Pendidikan Agama Islam agar dapat mengoptimalkan keterampilan pengelolaan kelas baik yang berhubungan dengan Keterampilan penciptaan dan pemeliharaan kondisi belajar yang optimal (bersifat preventif) maupun Keterampilan yang berhubungan dengan pengembalian kondisi belajar yang optimal (bersifat kuratif). Hal ini agar bertujuan kondisi kelas terjaga dari awal sampai akhir proses pembelajaran.

2. Diharapkan Kepada kepala sekolah agar dapat memperhatikan pengelolaan kelas yang dilakukan oleh guru agama.

3. Diharapkan kepada Dinas Pendidikan agar dapat memperhatikan dan mempertimbangkan tentang keberadaan jam pelajaran yang hanya 2 jam perminggu yang disediakan untuk bidang studi Pendidikan Agama Islam.

4. Kepada siswa agar dapat bekerja sama dengan guru dalam menciptakan kondisi kelas yang optimal untuk proses pembelajaran. 
Al-Muaddib : Jurnal Ilmu-Ilmu Sosial \& Keislaman http://jurnal.um-tapsel.ac.id/index.php/al-muaddib/ issn online : 2549-0427 | issn cetak: 2528-2492 Volume 1 Nomor 2 ( Januari-Juni) 2019

\section{DAFTAR PUSTAKA}

Abdul Majid, Pendidikan Agama Islam Berbasis Kompetensi, Bandung: Remaja Rosdakarya, 2006.

Nana Sudjana, Dasar-dasar Proses Belajar Mengajar, Bandung: Sinar Baru Algesindo, 2011.

Syafrudin Nurdin, Basyiruddin Usman, Guru Profesional dan Implementasi Kurikulum, Jakarta: Ciputat press, 2004.

Syaiful Bahri Djamarah, Guru Dan Anak Didik Dalam Interaksi Edukatif, Jakarta: PT. Rineka Cipta, 2000.

Undang-undang SISDIKNAS, Jakarta: Sinar Grafika, 2003.

UU No. 14 tahun 2005 tentang Guru dan Dosen, Bandung: Fermana, 2006.

Wina Sanjaya, Strategi Pembelajaran, Jakarta: PT. Rineka Cipta, 1966.

Zainal Asri, Micro Teaching, Jakarta: PT. Raja Grafindo, 2012.

Zakiah Drajat, Ilmu Pendidikan Islam, Jakarta: PT.Bumi Aksara, 1990. 